\title{
LONG-TERM BIRD RINGING IN PALESTINE
}

\author{
Simon I. Awad, Michael H. Farhoud, Riad K. Abu Saada \\ and Przemysław Busse
}

\begin{abstract}
Awad S.I., Farhoud M. H., Saada Abu R. K., Busse P. 2017. Long-term bird ringing in Palestine. Ring 39: 83-102.

This paper reports the results of mist-netting of birds, mainly passerines, at the Talitha Kumi ringing site by the Environmental Education Center (EEC), supported by the Evangelical Lutheran Church in Jordan and the Holy Land. Bird catching/ringing has been conducted there since 2000, but the data presented here are limited to ten years of work (2004-2013), mainly for compatibility reasons. During this time 6,810 individuals of 70 species were caught, of which 16 migrants and 8 local species caught most frequently are discussed. Data on seasonal (all year) and long-term (10-year) dynamics are given. The following general conclusions were drawn: (1) Even infrequent sampling of the local population by netting provides important information on seasonal and long-term patterns and trends; (2) the same is true of migrating species, provided that the work is carried out using the same methods over a long time span; (3) in migrants, very differentiated relations are observed between numbers of individuals caught during the spring and autumn migration seasons; (4) during the ten years of the study negative trends in the number of captured birds were observed for 14 species, including significantly negative trends for 4 species, while positive trends were observed for 10 , none of which was significant.
\end{abstract}

Corresponding author: Awad S.I., Farhoud M. H., Saada Abu R. K., Environmental Education Center, Muristan Road, Old City, P.O. Box 14076, Jerusalem 91140, East Jerusalem, Palestine; Busse P. (corredsponding author) Bird Migration Research Foundation, Przebendowo 3, 84-210 Choczewo, e-mail: busse@wbwp-fund.eu

Keywords: bird ringing, long-term number dynamics, seasonal dynamics, migrants, local birds

\section{INTRODUCTION}

Palestine enjoys a privileged geographical location, as it lies between three continents: Asia, Europe and Africa. Palestine is a small area compared to many other countries, yet its environment is varied and includes five biogeographical zones (Central Highlands, Semi-Coastal Region, Eastern Slopes, Jordan Rift Valley and Gaza Strip), in addition to four phyto-geographical regions (Mediterranean, Irano-Turanian, Saharo-Arabian, and Sudanese/Ethiopian). It consists of two physically separated landmasses: the West Bank (including East Jerusalem) and the Gaza Strip. 
There are about 51,000 living species in the State of Palestine, constituting approximately $3 \%$ of global biodiversity. There are more than 30,850 animal species, including an estimated 30,000 invertebrates, 373 birds, 297 fish, 92 mammals, 81 reptiles and 5 amphibians. The state of Palestine also hosts more than 2,000 species of plants, including 54 endemic plants that do not exist in any other part of the world. One of the best examples illustrating its biological significance is bird migration. Palestine together with the adjacent areas is one of the most important migration paths, with five hundred million birds passing each year through this natural bottleneck between the desert and the sea. The Jordan Rift Valley is part of the Great Rift Valley/Red Sea flyway, which is the second most important flyway for migratory soaring birds in the world and the most important route on the Africa-Eurasia flyway.

Since 1998, the Environmental Education Center (EEC), supported by The Evangelical Lutheran Church in Jordan and the Holy Land, has been dedicated to research on the natural history of the region of Palestine. This project also includes the study and conservation of the birds of Palestine.

Projects the EEC has completed include four bird ringing and monitoring stations in Palestine, the establishment of the first Natural History Museum in 1998, the sponsorship of conservation and field research projects involving bird ringing, monitoring, and surveys, and the establishment of a Botanical Garden. Partnerships with international organizations and institutes include the South Eastern European Bird Migration Network (SEEN), EURING, the Ornithological Society of the Middle East, previously Birdlife International, and recently the International Union for Conservation of Nature (IUCN).

Among other activities, the EEC runs four bird ringing and monitoring stations in Palestine in cooperation with SEEN: one permanent station in the Bethlehem area (Talitha Kumi) and three seasonal stations in the Jericho, Tulkaram and Jenin areas, representing cross sections of the West Bank.

As the first ringing site, the Talitha Kumi Ringing Station $\left(31^{\circ} 42^{\prime} \mathrm{N}, 35^{\circ} 12^{\prime} \mathrm{E}\right)$ began its work in 2000 as the site for training of the Palestinian team. It has been manned continuously since that time, and the data obtained there are the basis for this publication. Some data from other stations have previously been published in short activity reports from single seasons (Awad et al. 2013, Awad and Rząd 2014).

The second station is located in Jericho City in the Jericho District ( $\left.31^{\circ} 51^{\prime} \mathrm{N}, 35^{\circ} 27^{\prime} \mathrm{E}\right)$, and is called Jericho Ringing Station (JRS). Jericho City is located in the Jordan Valley north of the Dead Sea and has an arid climate, but can also be considered an oasis due to its natural springs and the availability of surface water. The main study area is located in the southern part of the Wadi Quelt seasonal stream near Wadi Hejla and the adjacent wadi, $2 \mathrm{~km}$ to the north. In addition, the study area is located south of the main dump site for Jericho. This area is a rich oasis with a high abundance of plant life, including Zizipus spina-christi, Tamarix aphyla, Acacias, Atriplex lasiantha, Atriplex halimus and Datura innoxia. Some data from this station have previously been published (Awad et al. 2013, Awad and Rząd 2014).

The third station is located in Tulkarem in the northern region of the West Bank $\left(32^{\circ} 18^{\prime} \mathrm{N}, 35^{\circ} 01^{\prime} \mathrm{E}\right)$, around $15 \mathrm{~km}$ from the Mediterranean Sea. It receives relatively high rainfall and its land is suitable for farming. Its geographic location gives it 
a warm, subtropical climate, which allows for plentiful growth of fruit trees. The ringing station was run in cooperation with Al-Najah University. The bird ringing station includes an open area and fields, a forested area, and areas planted with fruit trees, providing a range of natural and cultivated habitats to attract birds. The area is rich in loquat trees along with other types of trees, including olive, guava, pomegranate, apple and various types of citruses.

The fourth station, established in 2016 near Jenin, is considered a seasonal ringing station. It is located in the northern part of Palestine ( $\left.32^{\circ} 28^{\prime} \mathrm{N}, 35^{\circ} 18^{\prime} \mathrm{E}\right)$, bounded by the Nablus and Tulkarem districts from the south and south-west and by the 1948 cease-fire line from other directions. The district is located between 90 and $750 \mathrm{~m}$ above sea level. Owing to the soil fertility and availability of water in the area, the Jenin district is considered one of the best agricultural areas in Palestine. The climate is governed by its position on the eastern Mediterranean, with moderate and rainy winters and hot and dry summers. The major native vegetation cover consists of Quercus calliprinos, Pistacia palaestina, Pistacia lentiscus, Pistacia atlantica and Amygdalus korschinskii. In addition, field crops (mainly wheat and barley), vineyards and olive and fruit trees dominate this land, particularly on valley shoulders.

By October 2015, the EEC had already ringed a total of 14,686 birds of 120 species. The EEC has published the first official Checklist of the Birds of Palestine, with 373 bird species identified in the State of Palestine (West Bank and Gaza Strip - 6,220 km²), representing 22 orders, 64 families, 30 subfamilies and 186 genera. The study area was selected where birds are most easily studied within the state of Palestine - the West Bank, including Jerusalem, and the Gaza Strip. This is the outcome of seventeen years of research and the use of scientific methods in the State of Palestine. This activity is an important supplement to the work of other ringing sites in the region: Hula Valley Bird Watching Center, Ramat HaNegev Birding Center, Jerusalem Bird Observatory and the International Birdwatching and Research Center in Israel, as well as ringing activities in the Azraq Oasis Protected Area, Wadi Dana, Dhleil and Hashimyyia in Jordan and in Burullus, Ashtoum, Wadi el Rayan, Hurghada, Sharm el Sheikh, Wadi Gemal, Aswan and Wadi Allaqi in Egypt. Unfortunately, there is no general overview of the data collected in this area, which is so important for the migration of birds following the SE European bird migration flyway. The only comprehensive presentation is available for Eilat (Morgan and Shirihai 1997) and eastern Egypt (Ibrahim and Busse 2012).

The aim of this article is to present a general picture of the seasonal and long-time dynamics of bird life obtained as a result of ten years of continuous ringing work in the stable habitat conditions of the Talitha Kumi site, using the same methods. As the first years of activity were highly differentiated, the ten-year period taken into account began in 2004 .

\section{THE TALITHA KUMI STUDY AREA}

The Bethlehem district is divided into three climatic regions. The Mediterranean region is located in the central and western portion of Bethlehem. The semi-arid region is located in the central and eastern part of Bethlehem. Finally, the arid region is found east of the Bethlehem district and extends to the cliffs of the Dead Sea. 
The Talitha Kumi Ringing Station is set in the EEC's botanical garden at the campus of Talitha Kumi School, located in the western part of the Bethlehem District, in the western part of the city of Beit Jala. It is situated in a mountainous area at an elevation of around $900 \mathrm{~m}$ above sea level, with a Mediterranean climate and a wide variety of native Palestinian species of plants, including Palestine Oak (Quercus calliprinos), Palestine Pistachio (Pistacia palestina), Palestine Buckthorn (Rhamnus palestina), Carob (Certonia siliqua), Hawthorn (Crataegus aronia), and Syrian pear (Pyrus syriaca), in addition to other species such as Aleppo Pine (Pinus halepensis), Olive (Olea europaea) and Mediterranean cypress (Cupressus sempervirens). During the months of April, May and June, the region is affected by the hot, dry, and dusty Khamaseen winds which blow in from the Arabian Desert.

\section{METHODS}

\section{Field work methods}

Standard ornithological and ringing work was performed about 2-4 days a week (Table 1) using 18-20 (usually 20) four-shelf mist nets, which were located in the same places. For about five hours daily the nets were checked every hour starting at sunrise. The field work methods, i.e. measurements (wing-length, tail-length and wing formula), body mass, fat score, and testing of the directional preferences of migrants, followed SEEN (SE European Bird Migration Network) standards (Busse 2000).

Table 1

Ringing activity of the Talitha Kumi Ringing Station. Results from 2004-2013 are presented in the article

\begin{tabular}{|c|c|}
\hline Years & Days per week \\
\hline 2000 & 29 Aug. -7 Oct. daily \\
\hline 2001 & $\begin{array}{c}\text { Spring }- \text { irregular } \\
\text { Autumn }-2 \text { days }\end{array}$ \\
\hline $2002-2007$ & 2 days \\
\hline 2008 & $\begin{array}{c}\text { Spring }-2 \text { days } \\
\text { Autumn }-3 \text { days }\end{array}$ \\
\hline $2009-2012$ & 4 days \\
\hline $2013-2014$ & $\begin{array}{c}\text { Spring }-4 \text { days } \\
\text { Autumn }-5 \text { days }\end{array}$ \\
\hline $2015-2017$ & 4 days \\
\hline
\end{tabular}

\section{Evaluation and presentation methods}

As the data-collection method was of a time-sampling nature with a number of irregularities, the data for analysis had to be standardized to achieve the highest possible compatibility. The basic sample was the result of catching of birds within one day, irrespective of the actual numbers of hours when the nets were open. Because of the data registration system used in several years of the study period, whereby days with 
no birds caught were not included in the ringing form, only days when at least one bird was caught were taken under consideration. These days were noted during a few years of the study, so it was possible to check whether ignoring zero-bird days influenced the resulting pattern to such a degree that it should be taken under consideration in further analysis. The example for 2004 is given in Figure 1: the differences in the general pattern were negligible, which was also the case for other years checked. For seasonal patterns, both general and species-specific, the source data for graphs and tables were expressed as mean numbers of birds caught per day of the specified decade (10-day period). In the graphs illustrating long-term dynamics, the mean number of birds caught per working day of the year was used (to present a more generalized pattern, in Fig. 2 these numbers were smoothed by a 5-position running average).

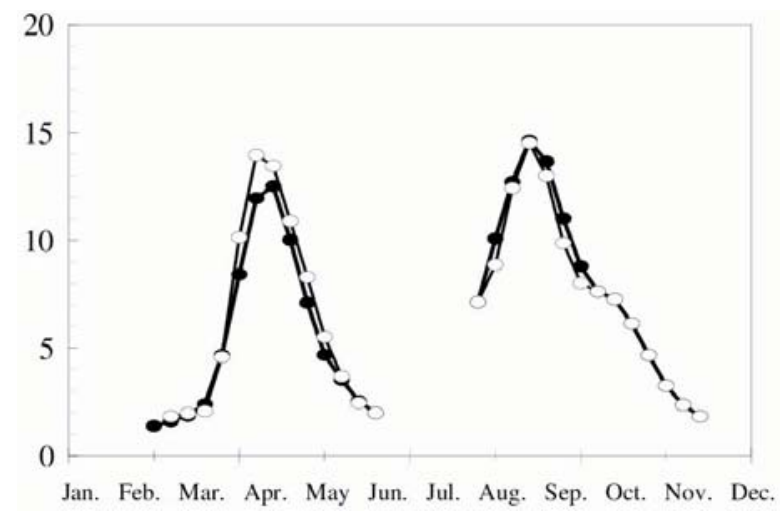

Fig. 1. Example of comparison of graph shapes with and without standardization of decade totals for working days with no bird caught (data from 2004; see discussion in text above)

\section{RESULTS AND COMMENTS}

\section{Catching and ringing results}

During the entire period of the study, 6,810 birds were ringed within 1,031 working days, for a mean of 6.90 individuals per day (Table 2). Apart from the individuals that were ringed, there were a few individuals that were not ringed (for various reasons, e.g. death or escape), but the full list in Table 3 contains these as well. Table 4 gives the number of individuals of more numerous species caught in successive years. The bird species are grouped according to their migratory status - migrants and local birds. This table provides absolute numbers of catches, while Table 5 gives more exact data about compatible mean frequencies in years, as the values for average daily catches account for varied catching activity in different years. 

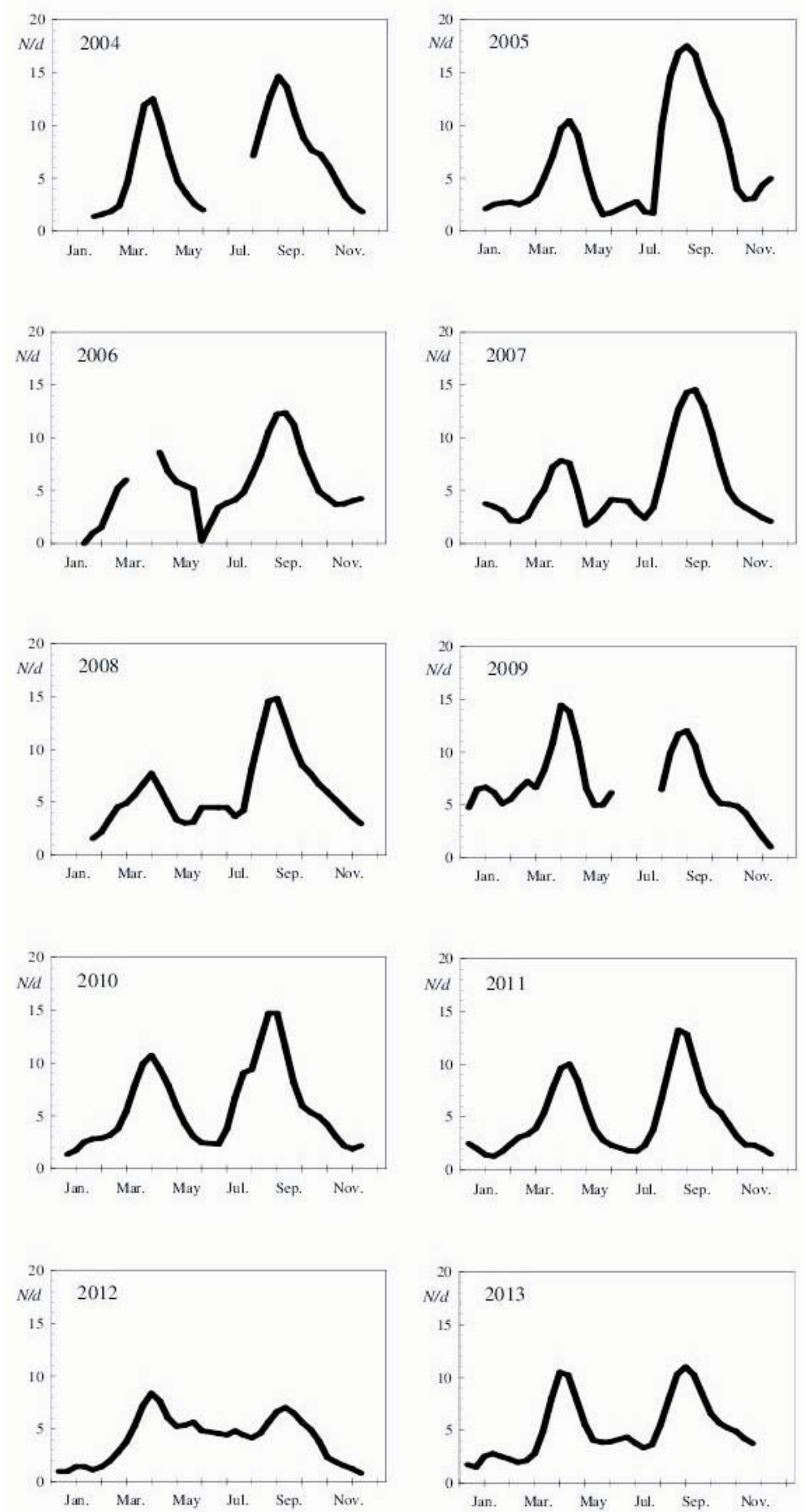

Fig. 2. Seasonal catching dynamics of all birds caught in different years, expressed as mean daily catches. Decade values smoothed by 5 -position running average. 
Table 2

Numbers of birds ringed, numbers of ringing days and mean number of birds ringed per day in each year

\begin{tabular}{|c|c|c|c|}
\hline Years & $\boldsymbol{N}$ ringed & $\boldsymbol{N}$ days & Per day \\
\hline 2004 & 433 & 63 & 6.87 \\
\hline 2005 & 467 & 56 & 8.34 \\
\hline 2006 & 399 & 52 & 7.67 \\
\hline 2007 & 417 & 58 & 7.19 \\
\hline 2008 & 582 & 84 & 6.93 \\
\hline 2009 & 864 & 109 & 7.93 \\
\hline 2010 & 998 & 145 & 6.88 \\
\hline 2011 & 853 & 136 & 6.27 \\
\hline 2012 & 751 & 149 & 5.04 \\
\hline 2013 & 1046 & 179 & 5.84 \\
\hline Total & $\mathbf{6 8 1 0}$ & $\mathbf{1 0 3 1}$ & $\mathbf{6 . 9 0}$ \\
\hline
\end{tabular}

Table 3

List of birds caught. Species codes are used in subsequent tables

\begin{tabular}{|c|c|c|c|}
\hline Code & Scientific name & English name & Total \\
\hline ACC.NIS & Accipiter nisus & Sparrowhawk & 1 \\
\hline ACR.ARU & Acrocephalus arundinaceus & Great Reed Warbler & 2 \\
\hline ACR.IRP & A. scirpaceus & Reed Warbler & 10 \\
\hline ACR.UST & A. palustris & Marsh Warbler & 9 \\
\hline ANT.CER & Anthus cervinus & Red-breasted Pipit & 4 \\
\hline APU.APU & Apus apus & Swift & 1 \\
\hline ATH.NOC & Athene noctua & Little Owl & 2 \\
\hline BUR.OED & Burrhinus oedicnemus & Stone-curlew & 1 \\
\hline CAP.EUR & Caprimulgus europaeus & Nightjar & 1 \\
\hline CAR.CHL & Carduelis chloris & Greenfinch & 98 \\
\hline CAR.INA & C. cannabina & Linnet & 13 \\
\hline CAR.SPI & C. spinus & Siskin & 2 \\
\hline CLA.GLA & Clamator glandarius & Great Spotted Cuckoo & 1 \\
\hline COR.RAX & Corvus cornix & Hooded Crow & 2 \\
\hline DEN.SYR & Dendrocopus syriacus & Syrian Woodpecker & 7 \\
\hline EMB.CAE & Emberiza caesia & Cretzschmar's Bunting & 6 \\
\hline EMB.CIA & E. cia & Rock Bunting & 1 \\
\hline EMB.CIT & E. cineracea & Cinereous Bunting & 1 \\
\hline EMB.HOR & E. hortulana & Ortolan Bunting & 93 \\
\hline ERI.RUB & Erithacus rubecula & Robin & 142 \\
\hline FAL.TIN & Falco tinnunculus & Kestrel & 3 \\
\hline FIC.ALB & Ficedula alba & Collared Flycather & 8 \\
\hline FIC.HYP & F. hypoleuca & Pied Flycatcher & 3 \\
\hline FIC.PAR & F. parva & Red-breasted Flycatcher & 1 \\
\hline FIC.SEM & F. semitorquata & Semi-collared Flycatcher & 4 \\
\hline
\end{tabular}




\begin{tabular}{|c|c|c|c|}
\hline Code & Scientific name & English name & Total \\
\hline FRI.COE & Fringilla coelebs & Chaffinch & 190 \\
\hline FRI.MON & F. montifringilla & Brambling & 3 \\
\hline GAR.GLA & Garrulus glandarius & Jay & 213 \\
\hline HAL.SMY & Halcyon smyrnensis & White-throated Kingfischer & 4 \\
\hline HIP.ICT & Hippolais icterina & Icterine Warbler & 1 \\
\hline HIP.OLI & H. olivetorum & Olive-tree Warbler & 12 \\
\hline HIP.PAL & H. pallida & Olivaceous Warbler & 79 \\
\hline JYN.TOR & Jynx torquilla & Wryneck & 5 \\
\hline LAN.COL & Lanius collurio & Red-backed Shrike & 32 \\
\hline LAN.NUB & L. nubicus & Masked Shrike & 12 \\
\hline LOC.FLU & Locustella fluviatilis & River Warbler & 3 \\
\hline LOC.LUS & L. luscinioides & Savi's Warbler & 4 \\
\hline LUS.LUS & Luscinia luscinia & Thrush Nightingale & 59 \\
\hline LUS.MEG & L. megarhynchos & Nightingale & 17 \\
\hline LUS.SVE & L. svecica & Bluethroad & 2 \\
\hline MER.API & Merops apiaster & Bee-eater & 1 \\
\hline MUS.STR & Muscicapa striata & Spotted Flycatcher & 43 \\
\hline NEC.OSE & Nectarinia osea & Palestine Sunbird & 3 \\
\hline OEN.HIS & Oenanthe hispanica & Black-eared Wheatear & 1 \\
\hline ORI.ORI & Oriolus oriolus & Golden Oriole & 5 \\
\hline OTU.SCO & Otus scops & Scops Owl & 1 \\
\hline PAR.MAJ & Parus major & Great Tit & 453 \\
\hline PAS.DOM & Passer domesticus & House Sparrow & 70 \\
\hline PHO.OCH & Phoenicurus ochruros & Black Redstart & 19 \\
\hline PHO.PHO & P. phoenicurus & Redstart & 199 \\
\hline PHY.BON & Phylloscopus bonelli & Bonelli's Warbler & 18 \\
\hline PHY.COL & P. collybita & Chiffchaff & 220 \\
\hline PHY.LUS & P. trochilus & Willow Warbler & 150 \\
\hline PHY.SIB & P. sibilatrix & Wood Warbler & 11 \\
\hline PYC.XAN & Pycnonotus xanthopygos & Spectacled Bulbul & 79 \\
\hline SAX.OLA & Saxicola rubicola & Stonechat & 2 \\
\hline STR.DEC & Streptopelia decaocto & Collared Dove & 3 \\
\hline STR.SEN & S. senegalensis & Laughing Dove & 21 \\
\hline STR.TUR & S. turtur & Turtle Dove & 3 \\
\hline SYL.ALA & Sylvia melanocephala & Sardinian Warbler & 96 \\
\hline SYL.ATR & S. atricapilla & Blackcap & 2947 \\
\hline SYL.BOR & S. borin & Garden Warbler & 132 \\
\hline SYL.COM & S. communis & Whitethroat & 30 \\
\hline SYL.CUR & S. curruca & Lesser Whitethroat & 702 \\
\hline SYL.HOR & S. hortensis & Orphean Warbler & 54 \\
\hline SYL.MYS & S. mystacea & Ménétries's Warbler & 1 \\
\hline SYL.NIS & S. nisoria & Barred Warbler & 7 \\
\hline SYL.RUE & S. rueppelli & Rüppell's Warbler & 4 \\
\hline TUR.MER & Turdus merula & Blackbird & 461 \\
\hline TUR.PHI & T. philomelos & Song Thrush & 36 \\
\hline \multicolumn{3}{|l|}{ Total } & 6824 \\
\hline
\end{tabular}


Table 4

Yearly totals for more numerous species, discussed later. Species codes as in Table 3

\begin{tabular}{|c|c|c|c|c|c|c|c|c|c|c|}
\hline Species & 2004 & 2005 & 2006 & 2007 & 2008 & 2009 & 2010 & 2011 & 2012 & 2013 \\
\hline \multicolumn{11}{|c|}{ Migrants } \\
\hline SYL.ATR & 201 & 231 & 185 & 201 & 227 & 406 & 430 & 406 & 279 & 381 \\
\hline SYL.CUR & 48 & 47 & 31 & 27 & 54 & 123 & 114 & 101 & 58 & 99 \\
\hline PHY.COL & 8 & 17 & 9 & 1 & 46 & 50 & 45 & 32 & 3 & 9 \\
\hline FRI.COE & 19 & 13 & 18 & 14 & 20 & 30 & 20 & 5 & 6 & 45 \\
\hline PHO.PHO & 10 & 20 & 19 & 17 & 22 & 32 & 24 & 11 & 26 & 18 \\
\hline PHY.LUS & 10 & 22 & 11 & 8 & 21 & 12 & 25 & 13 & 20 & 8 \\
\hline ERI.RUB & 3 & 4 & 12 & 13 & 18 & 15 & 21 & 16 & 7 & 33 \\
\hline SYL.BOR & 8 & 10 & 5 & 6 & 4 & 10 & 28 & 18 & 11 & 32 \\
\hline EMB.HOR & 7 & 2 & 4 & 1 & 18 & 4 & 14 & 0 & 7 & 36 \\
\hline HIP.PAL & 6 & 6 & 9 & 5 & 4 & 8 & 7 & 14 & 10 & 10 \\
\hline LUS.LUS & 2 & 1 & & 2 & 8 & 12 & 6 & 7 & 5 & 16 \\
\hline SYL.HOR & 5 & 2 & 4 & 4 & 1 & 9 & 5 & 11 & 7 & 6 \\
\hline MUS.STR & 1 & 4 & 1 & 1 & 5 & 6 & 5 & 2 & 15 & 3 \\
\hline TUR.PHI & 2 & 0 & 0 & 1 & 7 & 8 & 3 & 2 & 3 & 10 \\
\hline LAN.COL & 1 & 2 & 1 & 3 & 15 & 1 & 2 & 3 & 4 & 0 \\
\hline SYL.COM & 3 & 2 & 4 & 0 & 3 & 1 & 1 & 2 & 6 & 8 \\
\hline \multicolumn{11}{|c|}{ Local birds } \\
\hline TUR.MER & 18 & 14 & 25 & 44 & 39 & 32 & 52 & 64 & 83 & 90 \\
\hline PAR.MAJ & 33 & 36 & 29 & 32 & 28 & 37 & 71 & 37 & 73 & 77 \\
\hline GAR.GLA & 9 & 8 & 7 & 17 & 13 & 9 & 25 & 24 & 38 & 63 \\
\hline CAR.CHL & 8 & 3 & 7 & 3 & 9 & 15 & 24 & 6 & 17 & 6 \\
\hline SYL.ALA & 10 & 5 & 4 & 4 & 3 & 5 & 13 & 10 & 23 & 19 \\
\hline PYC.XAN & 4 & 8 & 4 & 4 & 5 & 5 & 11 & 13 & 15 & 10 \\
\hline PAS.DOM & 5 & 1 & 2 & 0 & 1 & 7 & 7 & 18 & 10 & 19 \\
\hline STR.SEN & 0 & 1 & 2 & 0 & 1 & 5 & 6 & 2 & 2 & 2 \\
\hline
\end{tabular}

Table 5

Numbers of working days and mean numbers of species individuals caught per day in successive years

\begin{tabular}{|c|c|c|c|c|c|c|c|c|c|c|}
\hline & 2004 & 2005 & 2006 & 2007 & 2008 & 2009 & 2010 & 2011 & 2012 & 2013 \\
\hline Days $(d)>$ & 63 & 56 & 52 & 58 & 84 & 109 & 145 & 136 & 149 & 179 \\
\hline \multicolumn{11}{|c|}{ Migrants } \\
\hline SYL.ATR & 3.19 & 4.13 & 3.56 & 3.47 & 2.70 & 3.72 & 2.97 & 2.99 & 1.87 & 2.13 \\
\hline SYL.CUR & 0.76 & 0.84 & 0.60 & 0.47 & 0.64 & 1.13 & 0.79 & 0.74 & 0.39 & 0.55 \\
\hline PHO.PHO & 0.16 & 0.36 & 0.37 & 0.29 & 0.26 & 0.29 & 0.17 & 0.08 & 0.17 & 0.10 \\
\hline PHY.COL & 0.13 & 0.30 & 0.17 & 0.02 & 0.55 & 0.46 & 0.31 & 0.24 & 0.02 & 0.05 \\
\hline FRI.COE & 0.30 & 0.23 & 0.35 & 0.24 & 0.24 & 0.28 & 0.14 & 0.04 & 0.04 & 0.25 \\
\hline PHY.LUS & 0.05 & 0.39 & 0.21 & 0.14 & 0.25 & 0.11 & 0.17 & 0.10 & 0.13 & 0.04 \\
\hline ERI.RUB & 0.05 & 0.07 & 0.23 & 0.22 & 0.21 & 0.14 & 0.14 & 0.12 & 0.05 & 0.18 \\
\hline SYL.BOR & 0.13 & 0.18 & 0.10 & 0.10 & 0.05 & 0.09 & 0.19 & 0.13 & 0.07 & 0.18 \\
\hline
\end{tabular}




\begin{tabular}{|c|c|c|c|c|c|c|c|c|c|c|}
\hline & 2004 & 2005 & 2006 & 2007 & 2008 & 2009 & 2010 & 2011 & 2012 & 2013 \\
\hline Days $(d)>$ & 63 & 56 & 52 & 58 & 84 & 109 & 145 & 136 & 149 & 179 \\
\hline EMB.HOR & 0.11 & 0.04 & 0.08 & 0.02 & 0.21 & 0.04 & 0.10 & 0.00 & 0.05 & 0.20 \\
\hline HIP.PAL & 0.10 & 0.11 & 0.17 & 0.09 & 0.05 & 0.07 & 0.05 & 0.10 & 0.07 & 0.06 \\
\hline LUS.LUS & 0.03 & 0.02 & 0.00 & 0.03 & 0.10 & 0.11 & 0.04 & 0.05 & 0.03 & 0.09 \\
\hline SYL.HOR & 0.08 & 0.04 & 0.08 & 0.07 & 0.01 & 0.08 & 0.03 & 0.08 & 0.05 & 0.03 \\
\hline MUS.STR & 0.02 & 0.07 & 0.02 & 0.02 & 0.06 & 0.06 & 0.03 & 0.01 & 0.10 & 0.02 \\
\hline TUR.PHI & 0.02 & 0.00 & 0.00 & 0.02 & 0.08 & 0.07 & 0.02 & 0.01 & 0.02 & 0.06 \\
\hline LAN.COL & 0.05 & 0.04 & 0.02 & 0.05 & 0.18 & 0.01 & 0.01 & 0.02 & 0.03 & 0.00 \\
\hline SYL.COM & 0.05 & 0.04 & 0.08 & 0.00 & 0.04 & 0.01 & 0.01 & 0.01 & 0.04 & 0.04 \\
\hline \multicolumn{11}{|c|}{ Local birds } \\
\hline TUR.MER & 0.29 & 0.25 & 0.48 & 0.76 & 0.46 & 0.29 & 0.36 & 0.47 & 0.56 & 0.50 \\
\hline PAR.MAJ & 0.52 & 0.64 & 0.56 & 0.55 & 0.33 & 0.34 & 0.49 & 0.27 & 0.49 & 0.43 \\
\hline GAR.GLA & 0.14 & 0.14 & 0.13 & 0.29 & 0.15 & 0.08 & 0.17 & 0.18 & 0.26 & 0.35 \\
\hline CAR.CHL & 0.13 & 0.05 & 0.13 & 0.05 & 0.11 & 0.14 & 0.17 & 0.04 & 0.11 & 0.03 \\
\hline SYL.ALA & 0.13 & 0.09 & 0.08 & 0.07 & 0.04 & 0.05 & 0.09 & 0.07 & 0.15 & 0.11 \\
\hline PYC.XAN & 0.06 & 0.14 & 0.08 & 0.07 & 0.06 & 0.05 & 0.08 & 0.10 & 0.10 & 0.06 \\
\hline PAS.DOM & 0.08 & 0.02 & 0.04 & 0.00 & 0.01 & 0.06 & 0.05 & 0.13 & 0.07 & 0.11 \\
\hline STR.SEN & 0.00 & 0.02 & 0.03 & 0.00 & 0.02 & 0.08 & 0.10 & 0.03 & 0.03 & 0.03 \\
\hline
\end{tabular}

\section{General yearly patterns of seasonal catching dynamics}

Very general yearly catching patterns for the years 2004-2013 are presented in Figure 2. In all years the pattern was defined mainly by migrant birds during spring and autumn passage time, which dominate in numbers over local, resident species. The number of migrants caught in the two migration seasons showed high seasonal and yearly variation: there were years in which the number of migrants in autumn was markedly higher than in spring $(2005,2007$ and 2008), moderately higher (2004, 2006, 2010, 2011 and 2013), but also lower (2009 and 2012). This requires further, more detailed studies, to learn whether the variation is mainly due to the characteristics of a few dominant species and their variable breeding and wintering success, weather patterns during migration seasons, or even different migration routes in spring and autumn that are independent of breeding and/or wintering conditions. However, this requires data from other sites where regular, intensive work is conducted.

\section{Species seasonal dynamics}

Analysis of the year-to-year differentiation of migration volumes and the timing of species passage was not possible due to the small number of yearly catches of species, but combined data from the entire study period (2004-2013) make it possible to show the average seasonal dynamics for a few more numerous species, both migrants (Fig. 3-1, 3-2) and local birds (Fig. 3-3). Differences between migration volumes for spring and autumn were extremely high. The passage of the Thrush Nightingale was very pronounced in spring, while in autumn this species was sporadic. In contrast, the 
Spotted Flycatcher, Red-backed Shrike and Willow Warbler showed an extremely low migration volume in spring, but quite pronounced movement in autumn. Other species showed varied patterns in this respect, with the Blackcap passing the study area in the same numbers in spring and autumn. Thus future studies on such details may provide a great deal of interesting results. Even the shapes of catching dynamics of local birds are differentiated (Fig. 3-3). The Blackbird showed year-round occupation of the study area, with pronounced growth of the total population in spring/summer because of the breeding season and then a reduction to its normal level. In the Great Tit, this pattern shows even greater contrast - after very sharp growth of the local population, the reduction in numbers was very pronounced, possibly due to mortality and dispersion over a larger area unsuitable for breeding. The Sardinian Warbler, despite its occurrence year round, showed a pattern similar to that of a summer visitor, only partly migratory. The most intriguing pattern among the locals was observed in the House Sparrow, which occurred exclusively during breeding time and then practically disappeared from the site. This could be due to aggregation of the families into flocks that used different habitats from those of the breeding pairs. A similar phenomenon has been observed in the Tulkarem University area, where the House Sparrow bred in high numbers in spring, but was practically absent in autumn (pers. inf. P. Busse, after 2015 observations).

\section{Special comments on local birds}

The local birds caught at the station have the special status of birds that spend their entire lives in a limited territory around the ringing site, so that they can be presented as dependent on the site habitats and environment described above.

Turdus merula (Blackbird, TUR.MER). While normally a resident bird breeding in the area, the Blackbird is migratory in some cases, so it may be considered a winter visitor. The Blackbird typically breeds from early March to July. Though the Blackbird does breed in the area, at the Talitha Kumi Ringing and Monitoring Station significantly more immature birds were captured than adults. Additionally, at the TKRMS more males than females were observed. An increasing number of Blackbirds were recorded at the station in the ten-year span from 2004-2013, totalling 461 Blackbirds.

Parus major (Great Tit, PAR.MAJ). The Great Tit is a very common resident bird in the Mediterranean climate, especially in the mountainous region in which the Talitha Kumi Ringing and Monitoring Station is located. Two captured individuals had rings from the Tel-Aviv ringing station, demonstrating the bird's common status in the area. Despite its common resident status, the number of these birds declined. During the ten-year span from 2004 to 2013, 453 Great Tits were caught, with the highest percentage of these birds caught from 2004-2007. While they were caught all year round, April through June were the peak months in which the Great Tit was observed. As in the case of many other bird species, more immature birds were recorded than adults.

Garrulus glandarius (Jay, GAR.GLA). The Jay is a common resident bird whose numbers increased during the observation period from 2004-2013. In total, 213 Jays were recorded during that period, with the highest percentages of observations and catches occurring from 2006-2008 and 2012-2013 during the peak months of May, 

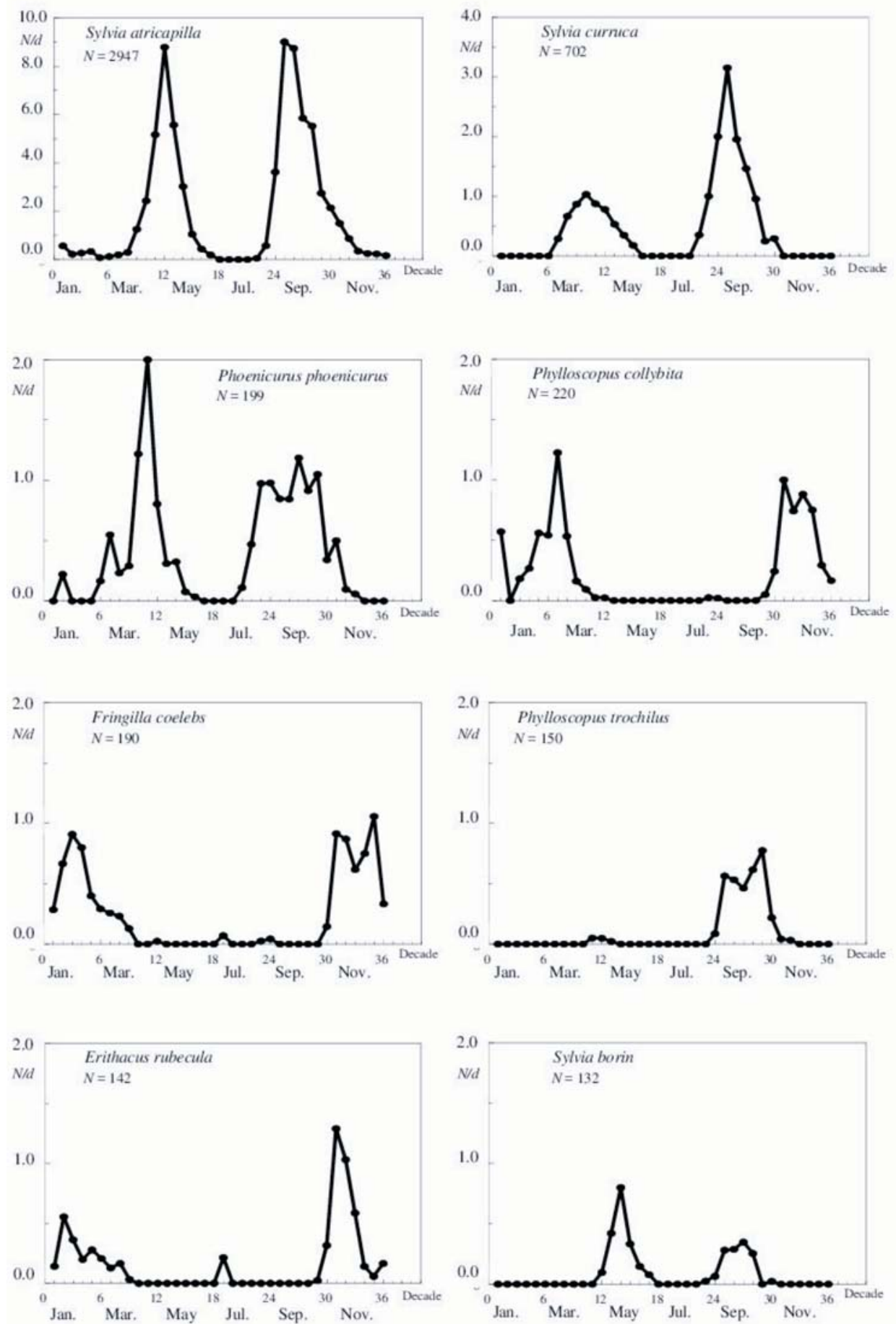

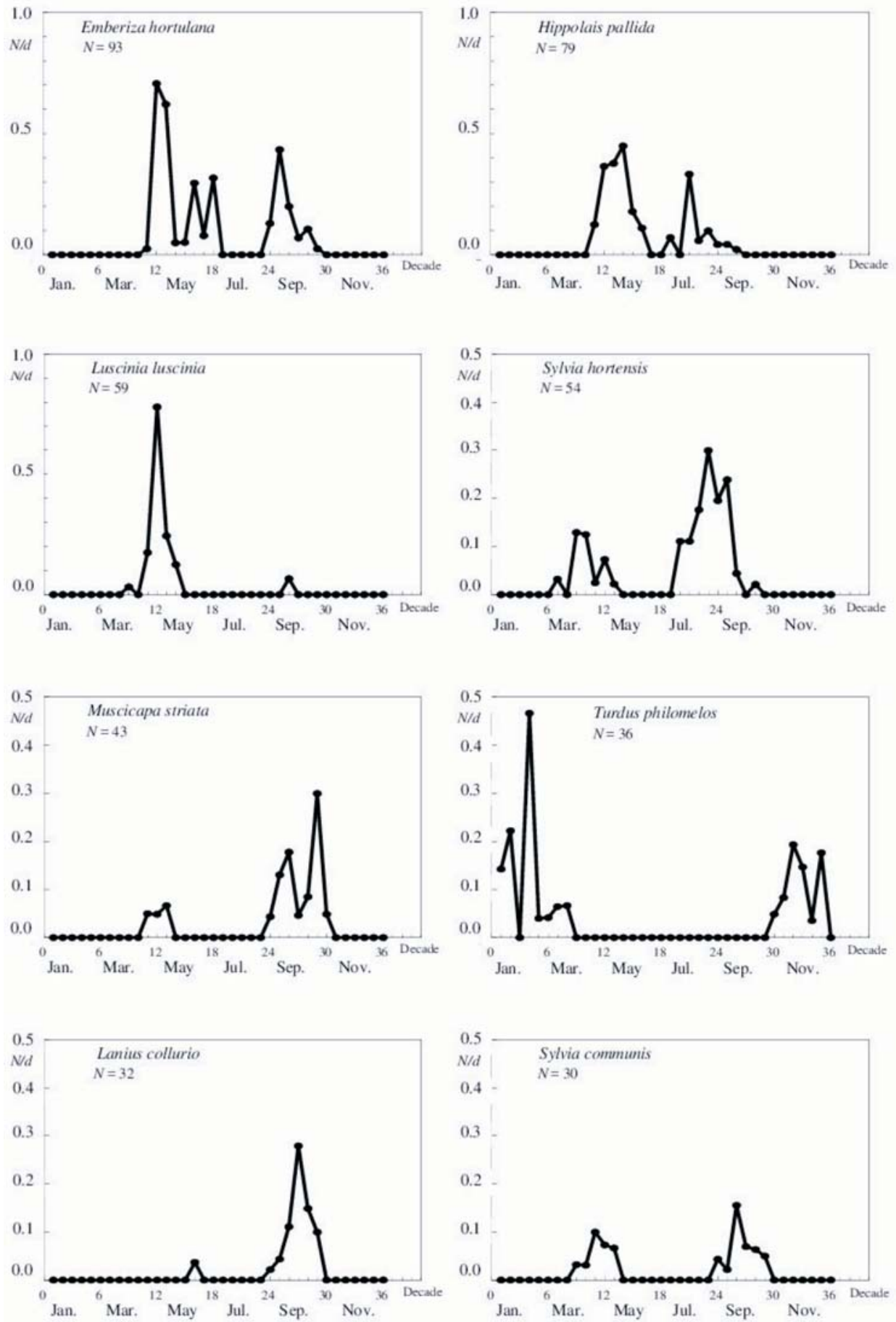

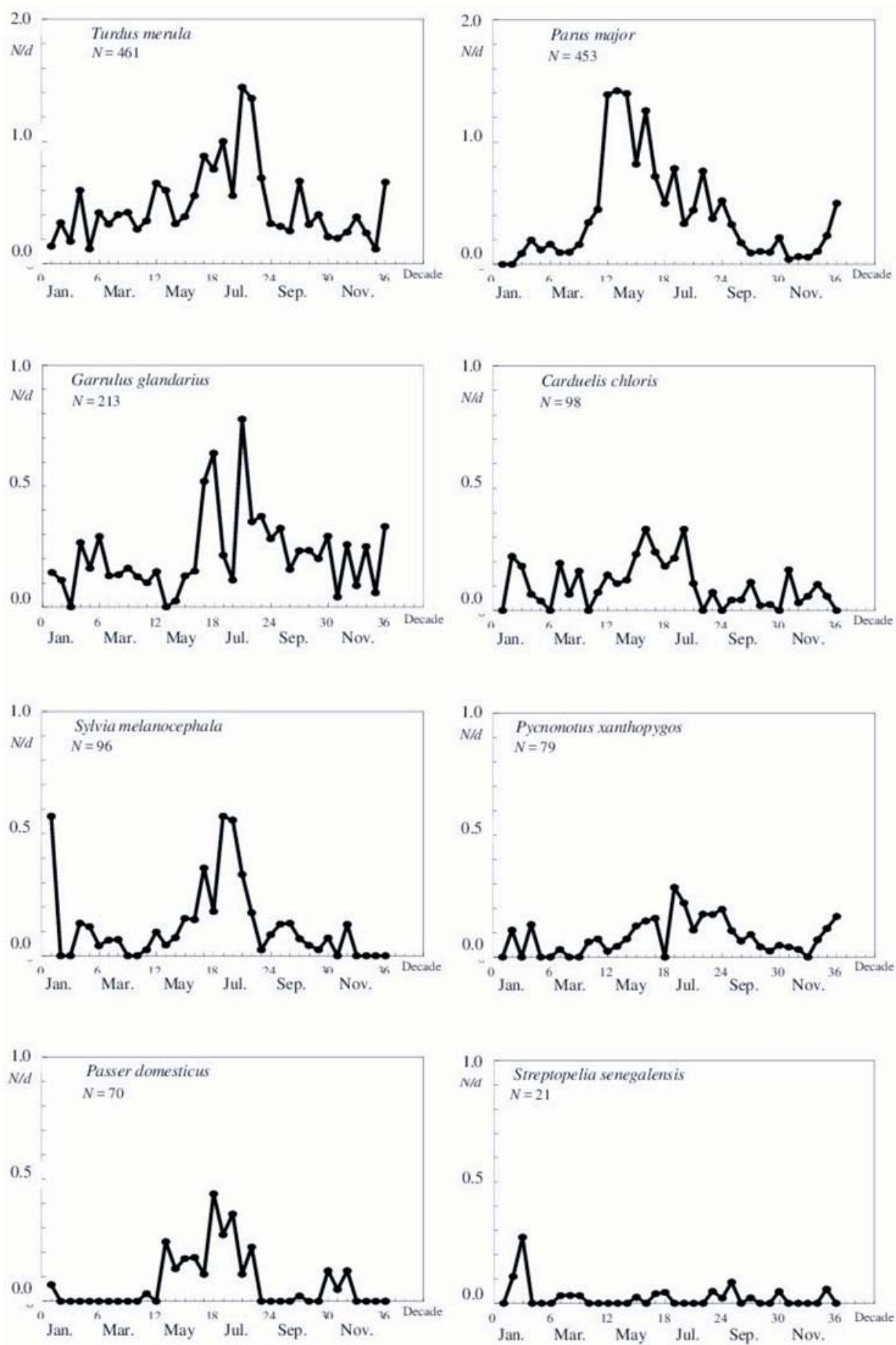

Fig. 3. Seasonal catching dynamics of individual bird species, expressed as mean daily catches 
June and July. Birds representing all age-classes were observed, but unlike other birds, very young fledglings were occasionally caught as well.

Carduelis chloris (Greenfinch, CAR.CHL). The Greenfinch is a very common resident bird, which is also occasionally classified as a passage migrant and a winter visitor. Despite being a resident species, the observed number of Greenfinches showed some decline during the years 2004-2013. In total, 98 individuals of this species were caught during that period, with the highest observation percentages recorded in May-July. Of the birds caught, the fat level remained at zero in all birds. Additionally, we caught more females than males and more adult birds than immature ones.

Pycnonotus xanthopygos (Spectacled Bulbul, PYC.XAN). The Spectacled Bulbul is a common resident bird in Palestine and specifically around the Talitha Kumi Bird Ringing and Monitoring Station. These birds do breed in the area, but we have not yet found a juvenile bird in the area. More of these birds were caught from 2004 to 2006 than in subsequent years.

Passer domesticus (House Sparrow, PAS.DOM). The House Sparrow is another example of a bird species that breeds in the Talitha Kumi area. Since 2008, the number of House Sparrows captured has increased, and in 2013, it was the most frequently caught bird at the site. At Talitha Kumi, more females than males were typically observed and captured, and more adults were captured than immature birds.

Streptopelia senegalensis (Palm Dove, STR.SEN). The Palm Dove is a common resident bird that breeds in the Talitha Kumi area. Because it is able to escape from the mist nets used at Talitha Kumi, the number of ringed Palm Doves was significantly lower than usual for a common resident bird.

Sylvia melanocephala (Sardinian Warbler, SYL.ALA). This is a special case in which the species is a common passage migrant, winter visitor and common resident bird. It is one of a few bird species whose number remained stable from 2004 to 2013. About 96 birds were ringed during that time.

\section{Long-term number dynamics}

Some of the most interesting results and the most valuable knowledge for bird protection activity may be obtained by long-term catching and ringing programmes. The data presented clearly show that even sampling that is not very intensive, but regular, can bring interesting results that may be used for regional comparisons. Figure 4 presents the results of regression analysis for separate species with relatively high total numbers caught (listed in Tables 2-3; seasonal dynamics of catches presented in Fig. 3). The trends for a few species, i.e. the Blackcap, Redstart, Chaffinch and the Willow Warbler, were significantly negative $(p<0.05)$, but there were also negative trends for ten other species, while non-significant but positive trends were noted for ten species. According to the signs test, this pattern shows that the general trend is negative with a probability of 0.85 - not statistically significant at the commonly used 0.05 level, but in agreement with the regression analysis. There was a difference between the group of migrants (eleven negative against five positive trends) and the local species (three negative against five positive trends). The general pattern of the long-term changes in bird catching at Talitha Kumi is presented in Figure 4. The results of the analysis of the total number of birds 

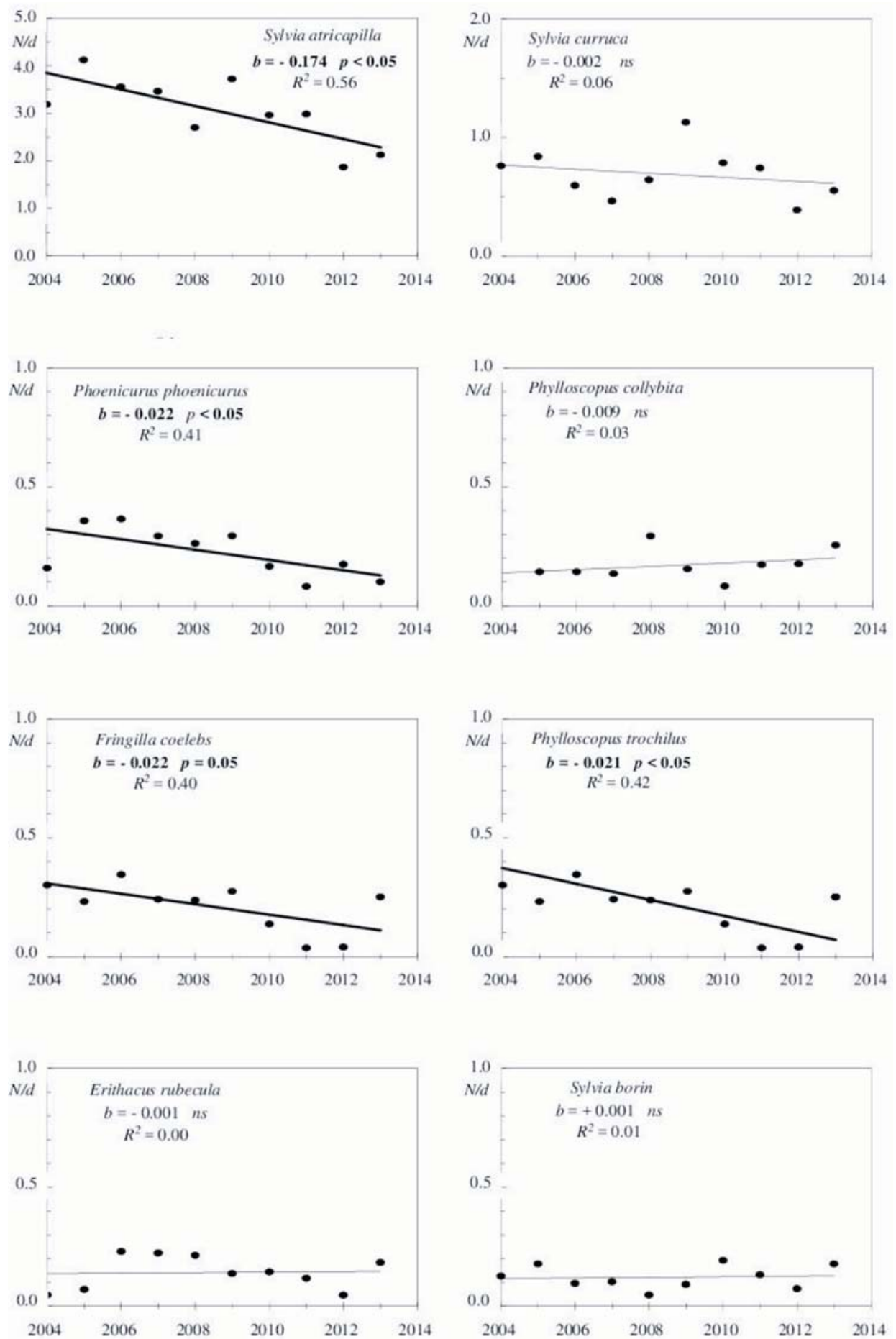

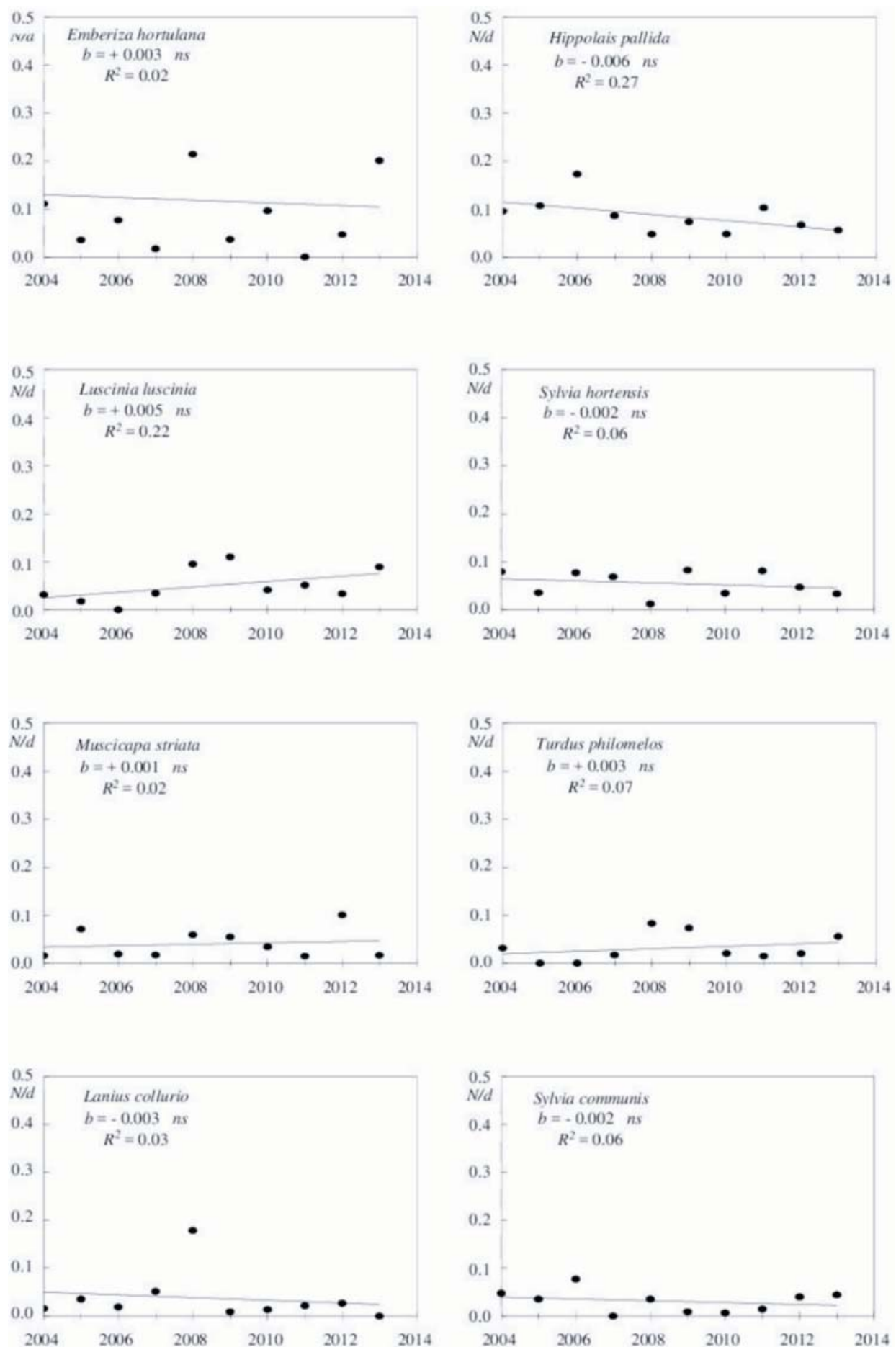

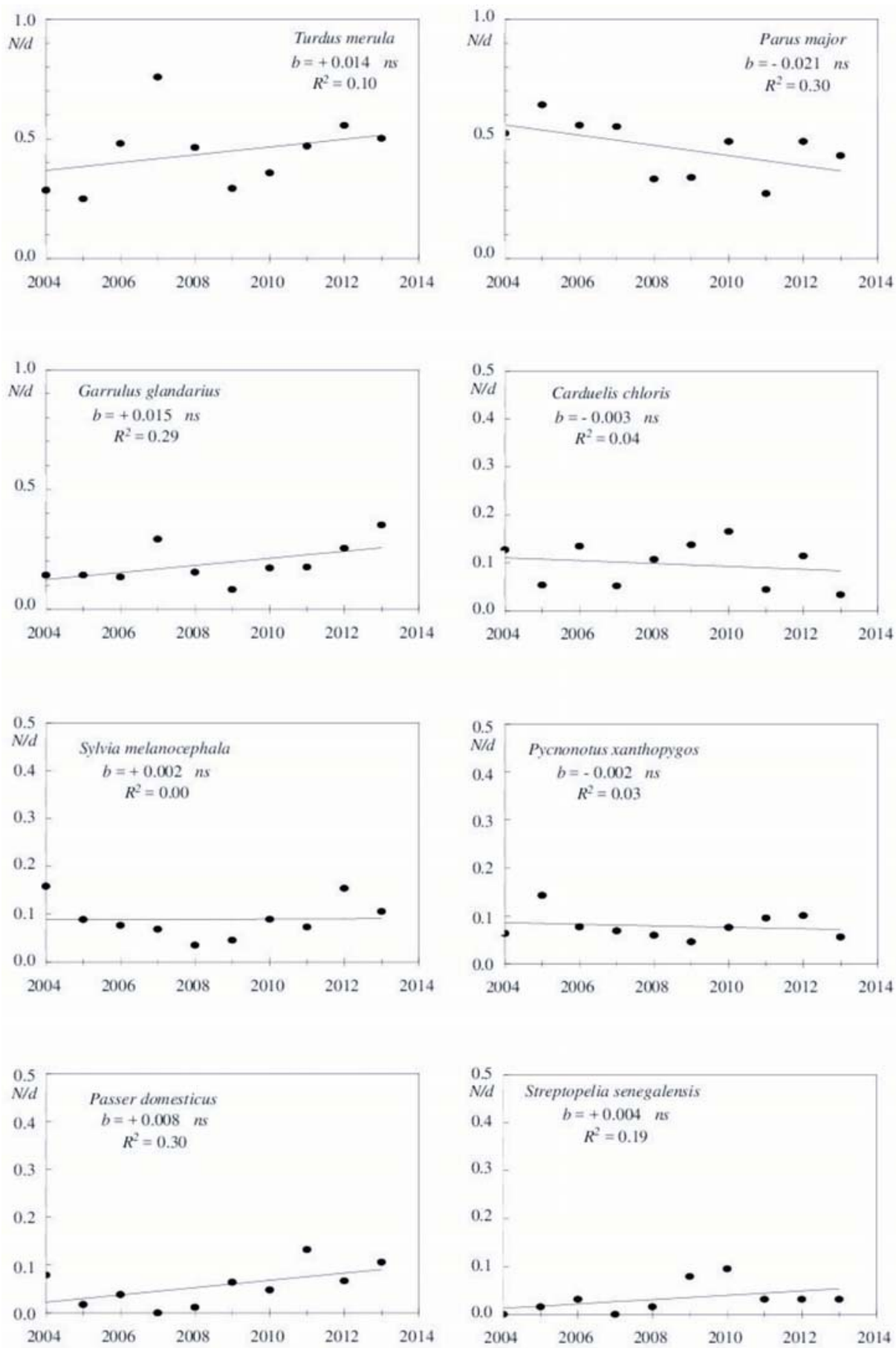

Fig. 4. Long-term number dynamics (2004-2013) for species, expressed as mean daily catches. Coefficient $b$ of the regression equation is given, with its significance $p$ (ns when $p<0.05$ ) and the $R^{2}$ value. Approximate regression line is drawn: thick line if $p$ is significant at $\geq 0.05$, thin line if $p$ is insignificant. 
caught per day against years showed a statistically significant decline, with a regression coefficient of $-0.24(p<0.05)$.

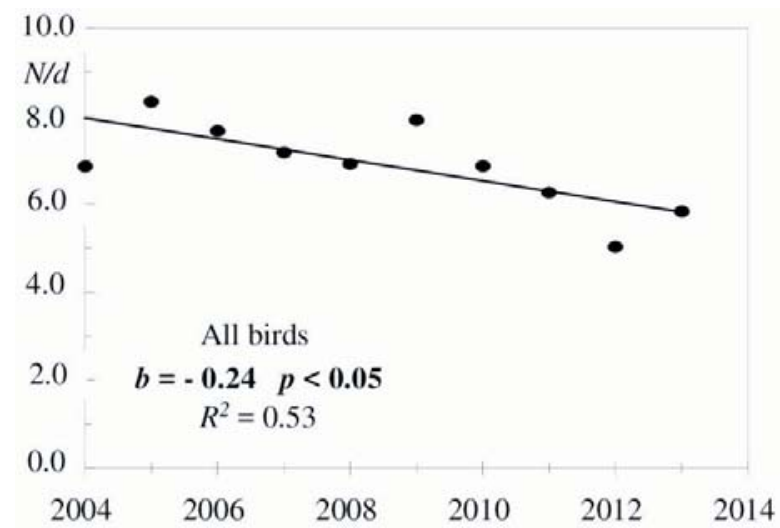

Fig. 5. Long-term catching number dynamics (2004-2013) for all birds caught, expressed as mean daily catches. Coefficient $b$ of the regression equation $(y=b x+c)$ is given, with its significance $(p<0.05)$ and the $R^{2}$ value. Regression line is drawn.

\section{CONCLUSIONS}

1. Even relatively infrequent sampling by netting of the local population provides important information about seasonal and long-term patterns and trends in numbers.

2. The same is true of migrating species, provided that the work is carried out using the same methods over a long time span.

3. In migrants, very pronounced differences are observed between the numbers of individuals caught during the spring and autumn migration seasons.

4. Over the ten-year time-span of the study, more negative trends in the number of captured birds were observed (14 species, including four significantly negative) than positive ones (10 species, none significantly positive).

\section{ACKNOWLEDGEMENTS}

We would particularly like to express our gratitude to the team of the SEEN network for their efforts and support over two decades of cooperation.

We are also thankful to the leaders and staff of ELCJHL, BMW and EEC for their support and cooperation.

\section{REFERENCES}

Awad S., Rząd I., Busse P. 3013. The ringing site in Jericho (Palestine) - development of bird migration and parasitological research on the Great Rift Valley flyway. Ring 35: 55-63. DOI 10.2478/ring-2014-0003. 
Awad S., Rząd I. 2014. Jericho (Palestine) spring 2014 ornithological and parasitological research results. Ring 36: 33-43. DOI 10.2478/ring-2013-0003.

Awad S., Abu Saada R., Farhoud M., Khair M., 2015. Checklist of the Birds of Palestine. Environmental Education Center /ELCJHL, Palestine.

Busse P. 2000. Bird Station Manual. University of Gdańsk. Gdańsk.

Ibrahim W. A. L., Busse P. 2012. Migration of passerines through some protected areas in the eastern part of Egypt. Ring 34: 69-205.

Morgan J. H., Shirihai H. 1997. Passerines and Passerine Migration in Eilat. Int. Birdw. Cent. Eilat Tech. Publ. Vol. 6, Number 1, pp. 50

General materials:

1. State of Palestine $5^{\text {th }}$ National Report (CBD) 2015

2. Environmental Profile for The West Bank. Volume 7. Jenin District. Applied Research Institute Jerusalem. 1996

3. Bethlehem A Pictorial Guide by the Center for Cultural Heritage Preservation

4. http://whc.unesco.org/uploads/nominations/1492.pdf

5. http://www.beitjala-city.org/index.php/en/

6. http://vprofile.arij.org/bethlehem/pdfs/VP/Artas_vp_en.pdf

7. http://cchp.ps/new/en/inventory-of-sites/archeological-sites/item/73-solomon-s-pools 